\title{
THE RELOCATION, CONSERVATION AND PRESERVATION OF KAMPUNG TELUK MEMALI MOSQUE IN KG. GAJAH, PERAK TO IPOH, PERAK, MALAYSIA
}

\author{
AZIM A. AZIZ \& MOHAMAD HAZIQ ZULKIFLI \\ ATSA Architects, Kuala Lumpur, Malaysia
}

\begin{abstract}
Relocation of a heritage building is one of the conservation methods that will effectively restore but also change the building setting permanently. In this research, relocation programme has been studied based on a real-life project of relocating and restoring a 108-year-old mosque from Kampung Gajah to Ipoh in Perak, Malaysia as the case study. Aspects of conservation methods, modern design and users' expectations and financial factor have been discussed in this study, with reference to the case study and related literature review. The study also explored the possible future solutions of many old and abandoned timber mosques or other notable timber structures in the country through relocation programme.

Keywords: relocation, dismantling, architecture, heritage, preservation.
\end{abstract}

\section{INTRODUCTION}

Traditional mosques in Malaysia were built within the loosely arranged rural residential quarters known as the kampungs (villages). The traditional Malay mosque is often built on a raised floor, either on stilts or platforms. It follows the typical Malay vernacular mosque typology and can be easily identified by its pyramidal roof on a square layout, where the prayer hall locates. Due to the unique features of the walls and made of timber materials, the traditional Malay mosque structure can be dismantled and shifted to a new site, if necessary, even though this practice is relatively uncommon nowadays. Most times, the older mosques were demolished to make way for bigger mosques to cater for the growing population.

Relocating timber buildings for it to be reused, nevertheless, is a common practice in the Malay house building culture. It is a common tradition that can be found in most traditional villages in the Malay Peninsular of even around the Nusantara region. Relocation has also been practised and the most preferred practice in salvaging various traditional Malay houses to be converted into outdoor museums and villas in upscale resorts.

\section{PROBLEM STATEMENTS}

As the surrounding semi-urban population grows, many villages in the rural areas were deserted, mainly due to the exodus of its residents, especially when today's youngsters are migrating to cities in search of a better lifestyle and most importantly good paying jobs. This has caused the abandonment of many built structures, including many traditional timber houses and mosques. In some areas, the kampungs have been displaced and relocated to other areas due to the government resettlement programme to help the villagers and at times upon their request.

The existence of many old, dilapidated and vacant century-old timber buildings in Malaysia, especially in the state of Perak of good structural with priceless historical treasures which have given rise to the critical necessity for the preservation of these structures. The relocation approach through dismantling and reinstallation on the new site may be applied, 
rather than the orthodox approach of restoring these structures in-situ, at its current site. This method may be the only way to salvage these buildings and to give it a new lease of life.

\section{AIM AND OBJECTIVES}

This study is aimed to document and record a real-life effort to successfully relocate and restore the traditional timber Malay mosque, the Kampung Teluk Memali Mosque. To further investigate and achieve the study aim, the study objectives have been outlined in the light of the approach of a successful relocation programme, in terms of the relocation methods and techniques, modern design and users' expectations and financial factor.

\section{LITERATURE REVIEW}

\subsection{Vernacular timber construction and materials}

Nonetheless, until recently, especially in the urban areas, the use of timber as the main material has been gradually replaced by more durable materials such as stone, brick and mortar, and concrete [1]. Until the 1960s, timber was widely used in many parts of the buildings, including the floors, internal walls, porches and verandas, ceilings, roofs, staircases, doors and windows.

However, in some areas, if the chengal is unavailable or scarce, other heavy or medium hardwoods often used, such as the balau, petaling, and merbau, whereas merbau is rarely used due to its characteristic of red-blood like sap, thought to be haunted [2].

Traditional Malay construction relied on the post and beams structure as the primary load bearing elements, with wooden or bamboo walls and thatched roof. Prefabricated construction methods were used where all the components are made and assembled on site allows the house to be dismantled and reassembled elsewhere at a different location [3].

\subsection{Relocation practice as a conservation effort}

Relocation is a process of moving the entire building to a new site, which is another form of reconstruction, due to the unsuitability of the original site [4]. However, the setback is that it would lose its original setting. Furthermore, from the viewpoint of the cultural heritage preservation, original location preservation is the best way, and relocation to preserve for it to be reused should only be the last resort [5]. It is often interpreted as a less desirable method but would be the last resort when other options are not viable.

Relocation is also inferred to the situation whereby if the valuable cultural property is being damaged irretrievably or is threatened by its environment, it may have to be moved to a more suitable environment and a reproduction substituted to maintain the unity of a site or building [6].

Similar issues coined when relocation is concerned. Two questions surfaced, whether the house be restored at its original site or does it need to be moved to a more suitable area [1]. As much as other buildings, removing a structure from its present site will lose its original settings and surroundings. As for traditional Malay architecture, it would lose its village setting and context, especially since a mosque, as it is a public activity centre. This is further emphasised the significance of the buildings do not always rely on its architecture and aesthetic appeal, but also its locations, surroundings and its original purposes and history [7].

\section{RESEARCH METHODOLOGY}

Research methodology defines on how the data and information about the research study can be obtained. The methodologies can be divided into qualitative techniques and explanatory 
research. The qualitative method looks into the why and how not just what, where and when. Data collection is taken from the journals, articles, books, websites and personal interviews. While the exploratory research method is a research and study analysis based on the selected case study of Kampung Teluk Memali Mosque, in both old and new sites located in Kampung Gajah and Ipoh in the state of Perak.

On-site observation and participation through the dismantling, relocation and reinstallation process under the auspices of ATSA Architects. Besides that, as-built measured drawings and report from Ungku Omar Polytechnic (PUO) have also been referred to analyse the history and construction method of the mosque.

\section{DATA ANALYSIS AND FINDINGS}

\subsection{Background of the case study}

This non-profitable CSR effort was initiated by ATSA Architects after they had a joint publication effort with Ungku Omar Polytechnic (PUO) back in 2014, for the publication of a monograph on mosque architecture in Malaysia entitled Masjid - Selected Mosques and Musollas in Malaysia. In researching and collating the suitable content materials for the book, ATSA Architects came across with such remarkable work which has been carried out by PUO in documenting various built heritage buildings, particularly in the state of Perak, including the Kampung Teluk Memali Mosque located in Kampung Gajah, Perak (Fig. 1). It was also suggested by PUO for ATSA Architects to lead a team to preserve the mosque by moving it to an area where it could be used again.

By looking at this neglected state and its heritage value, it was decided that there must be an immediate conservation intervention. ATSA Architects and faculty members of PUO began work hand in hand to obtain the duly permission to relocate and restore the mosque from the former villagers of Kampung Teluk Memali, as well as the Land and District Office of Central Perak, Islamic Religious and Malay Customs Council of Perak State (MAIPk), the Mufti Department of Perak State to seek the official fatwa (Islamic cleric) guidance in relocating the mosque and the Ipoh City Council (MBI) for the planning and building approval of the new site.

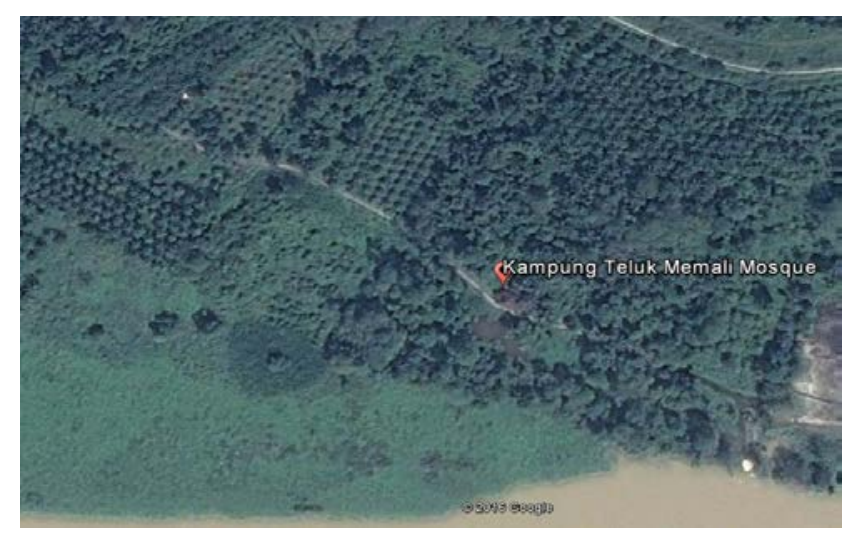

Figure 1: The former location of the mosque in $\mathrm{Kg}$ Teluk Memali in Kg Gajah, Perak, Malaysia. (Source: Google Earth, 2017.) 


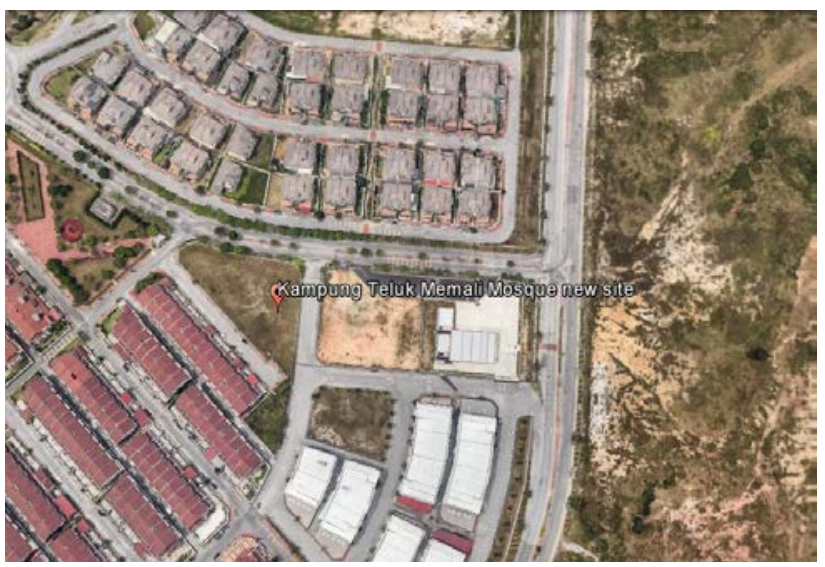

Figure 2: New location plan of the mosque in Bandar Seri Botani, Ipoh, Perak, Malaysia. (Source: Google Earth, 2017.)

A new site in Bandar Seri Botani, Ipoh, Perak was chosen as the local populace were in need of a surau (small mosque) for the neighbourhood, located about 10 kilometres in the south of Ipoh city centre (Fig. 2). The site has also been selected to ensure the continuity of architectural language of the mosque itself, which is the Perak Malay architectural style of mosque building typology. The current site in Bandar Seri Botani, Ipoh is located approximately 65 kilometres from the former site in Kampung Gajah, Perak.

\subsection{Background of the case study}

The mosque was constructed in 1908 and completed in 1910 with the cost of construction was donated by a wealthy man living in Kampung Teluk Memali. [8]. However, it also believed that the mosque was built years earlier, functioned as a surau and located on the edge of the river bank. Due to soil erosion, the mosque was relocated to its current site, which is around 100 metres (328 feet) from the riverbank. Since 20 years ago, the mosque had been left vacant and abandoned due to the rising flood waters (Fig. 3).

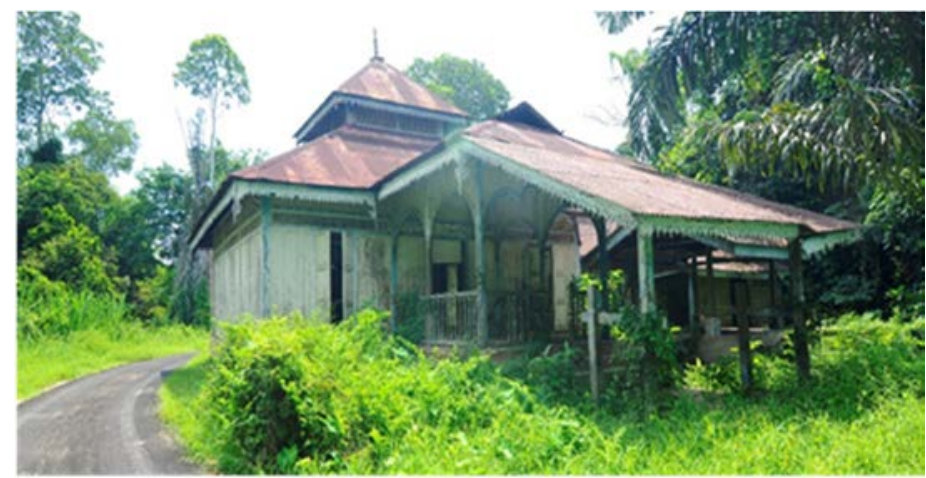

Figure 3: The mosque on the old site in Kg. Teluk Memali, Kg. Gajah, Perak. It was left abandon for approximately 20 years. (Source: ATSA Architects, 2015.) 
There is another evidence to support the claim of the year the mosque was built, which is carved on the intricate timber mimbar platform. At the rear side of the mimbar frame, an old Jawi inscription can be seen; and can be translated into English and read as 'Megat Jaafar on 15-11-1339.' The mentioned date is believed to be written using the Hijri calendar, which is equivalent to the Gregorian calendar of 21 st July 1921. The inscribed date could also be translated as the year when the mosque was built [9].

\subsection{Design concept and layout of Kampung Teluk Memali Mosque}

The layout of the mosque comprises the main mosque building and an annexe building known as balai lintang; the Kampung Teluk Memali Mosque was the main place of worship for the local Malay Muslim community ever since it was built. The main prayer hall is measuring 8.95 metres by 8.95 metres that can comfortably fit approximately 150 people (Fig. 4). It was used for daily solah jamaah (congregation prayers), other than the weekly Friday prayers, Eid prayers and other religious occasions such as the Eid sacrificial rites, Thanksgiving feasts or even formal or informal lessons in Islamic studies and the use of musical instruments such as kompang (wooden tambourine).

The main prayer hall building consists of an anjung (foyer) area, a welcoming area where a beduk (large drum) was once located to be used before the call for prayer five times a day by a rhythmic beating of the timber log, other than the serambi (veranda), the main prayer hall, mihrab and mimbar (Fig. 5). Meanwhile, the balai lintang is an additional building that is believed to be built later than the mosque building (Fig. 6). This is evident from the different and simpler architectural style of the building. The colour of the mosque is quite unusual. Bright yellow and turquoise blue were painted and used over the timber which emphasised the mosque building with other surrounding buildings at that time.

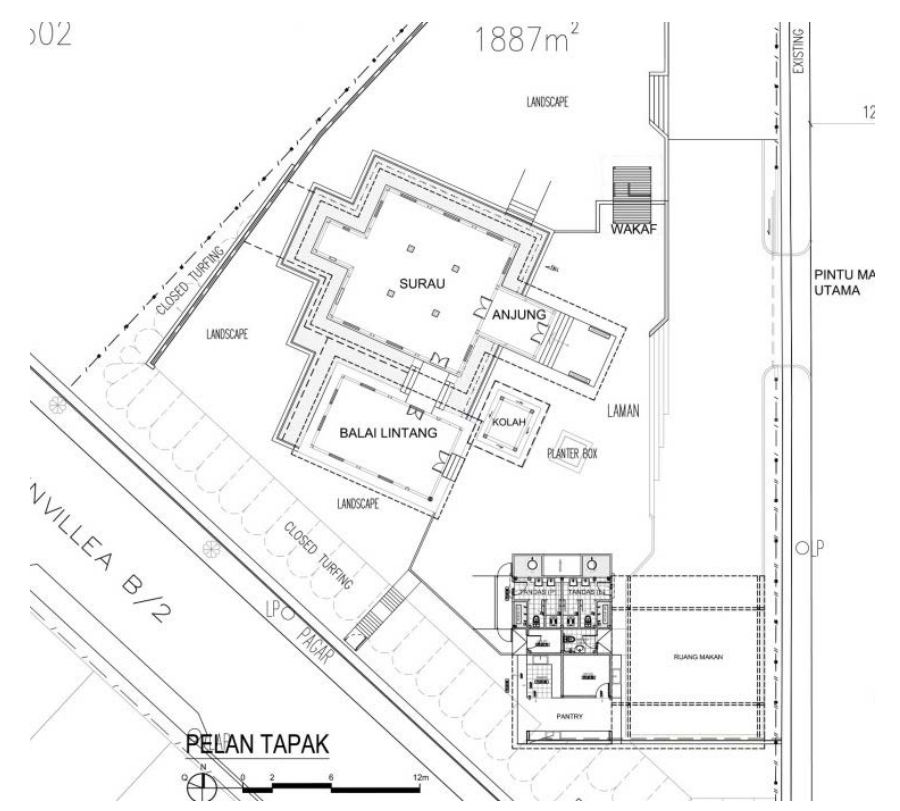

Figure 4: Site plan of new relocated site. (Source: ATSA Architects, 2015.) 

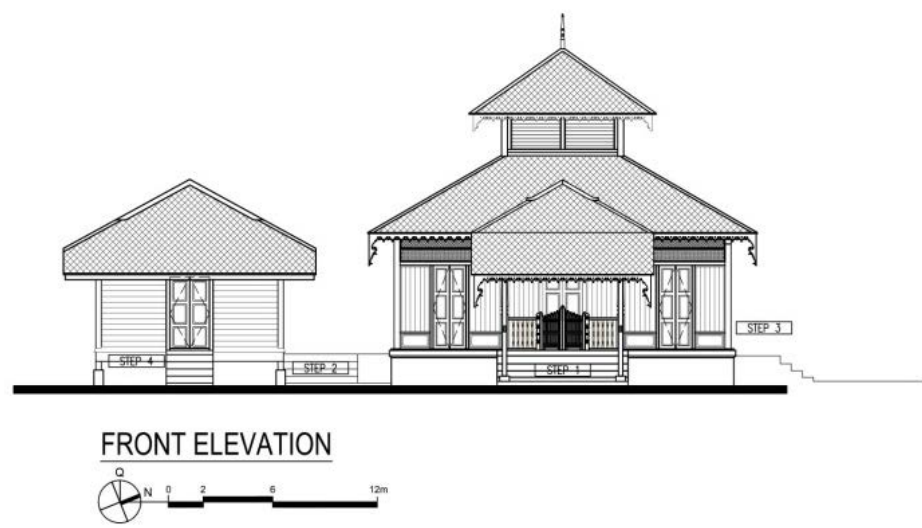

Figure 5: Front elevation. (Source: ATSA Architects, 2015.)
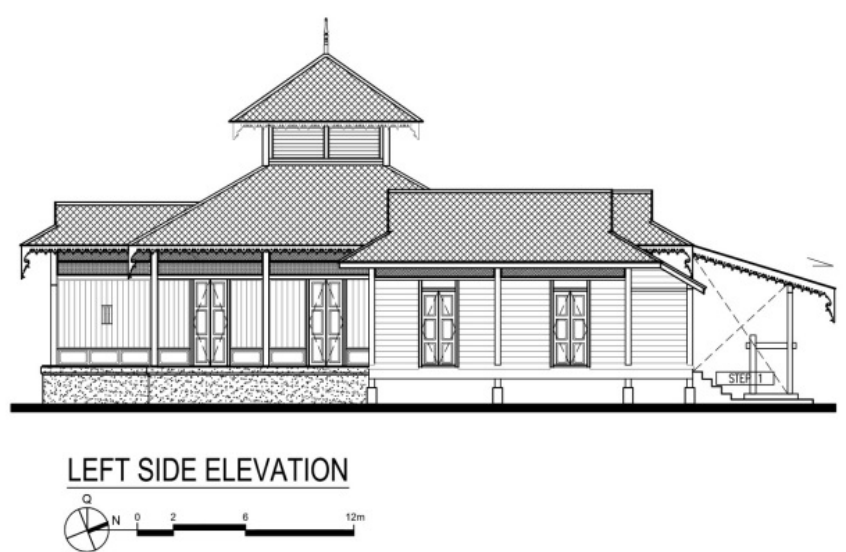

Figure 6: Left elevation. (Source: ATSA Architects, 2015.)

\subsection{Building materials}

Based on the timber structure pre-inspection test done by the Malaysian Timber Industry Board (MTIB) on the mosque building, the mosque structure is overwhelmingly made of a chengal hardwood timber for most of its components. The chengal can be seen in all of its structural columns, wall panels and other decorative elements of anjung, serambi and the main prayer hall. Other than chengal, balau can also be found in certain structural elements, except tualang of the wall panel skirting. Other than timber, several non-timber materials can also be found, such as the one metre (three feet) concrete platform base, corrugated zinc and asbestos sheet for the roofing materials. 


\section{DISCUSSION OF FINDINGS}

\subsection{Preliminary works and site operational}

Several little aspects that need to be considered in the preliminary works before any physical removal works take place [1]. The preliminary works, including the dilapidation survey and measured drawings, were deemed necessary in determining the mosque building conditions for the next steps of building relocation and restoration. However, before commencing technical works, including the dilapidation survey and measured drawings, it is important to obtain the prior approval and permission from the relevant authority bodies, including the former building owner and the new site management.

The cleaning works on the site were also necessary to ensure a clutter-free site throughout the dismantling works. Most importantly, sets of suitable tools and machinery must also be prepared to perform the dismantling tasks. To propel the dismantling works, a set of coding and numbering shall be done earlier on every single component of the structure. This was done through referencing with the measured drawings that were prepared earlier.

\subsection{Dismantling methods}

The dismantling works are the most crucial stage in any relocation practice. Based on the methods of dismantling works implemented in this mosque, the dismantling works can be divided into six major components that involved structural components of timber structures, which are the roofing, wall panels, floorings, joists, tie beams and columns in 24 to 29 detailed steps altogether (Fig. 7).

However, an additional step is identified for the Kampung Teluk Memali Mosque that had relocated the kolah structure first, followed by the structure building. This is due to the reason of managing the site properly, as the kolah was located nearby the mosque building. Thus, it was important to move the smaller and detached structure first, before proceeding into the dismantling of the main building.

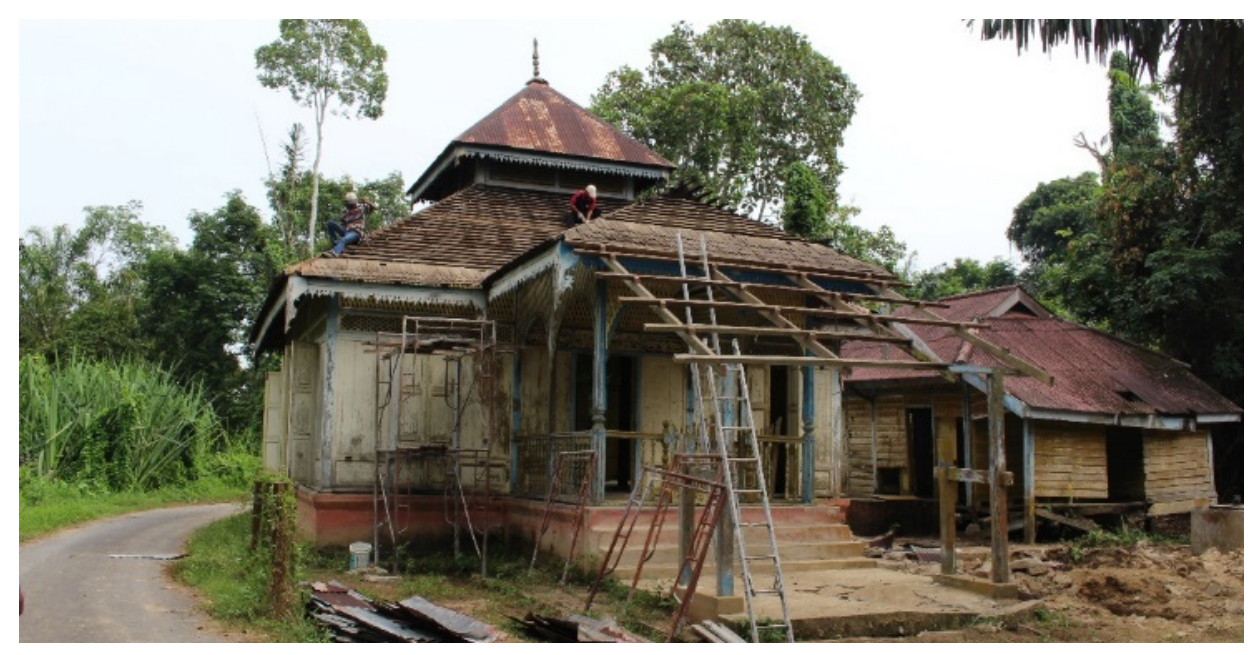

Figure 7: The dismantling works of the mosque on the old site. (Source: ATSA Architects, 2016.) 


\subsection{Loading and transportation}

Another important aspect of relocation is the loading and transportation process from the old site to the new site. After the dismantled components have been identified, collated and bundled, they must be kept and arranged properly inside the lorry or on a larger sized vehicle. This is important to ensure the materials are not messed up and can be unloaded properly. The length of the transportation depending on the distance between the old site and the new site.

As the new site will permanently change the contextual setting of the originally built forms, it is nonetheless suggested the building to be relocated within the same district or state to further maintain the regional architectural identity of that particular building, for instance, the Kampung Teluk Memali Mosque that had been relocated within the same state of Perak, from Kampung Gajah in the Central Perak district to Ipoh in Kinta District.

\subsection{Cleaning, repair and treatments}

Before the original timber can be used, it is important to have it sorted out and to identify which parts can be utilised or not. This can be identified after all components have been dismantled. It can be done either on the new site or in the designated workshops by the engaged contractors or carpenters. Should the existing wood is coated with a layer of paint, it is advisable to remove the existing paint layers by sanding process. This can be done using handy sanding devices or machines in nearby workshops.

After sanding, the repair process can be carried out accordingly. It is done based on the levels and types of defects and disrepair. This is when the carpentry skills are tested and needed in refurbishing the wood components. If the defects were severe, it might need to be replaced with new wood components, but there must be supervised by the appointed conservator in ensuring the project adhering to the conservation principles.

Meanwhile, the treatment process can be done either earlier or later, which is before the reinstallation of the wood components or after the structure has been completed. However, it is highly advisable to do before the reinstallation, as the treatment preserver would cover up any exposed surfaces, including the joints, which is imperative as a protective measure for the wood components. It can be executed either in the workshop or on the new site.

It is equally important to store the dismantled components, either treated or non-treated in a proper storage area on-site or off-site. This is to ensure the wood components are protected from the elements. Thus, they can be stored properly under a shaded canopy or tent and above the ground level, to avoid direct contact with the soil. Such measure had been prepared during the restoration of the Kampung Teluk Memali Mosque on its new site in Ipoh, Perak.

\subsection{Reinstallation methods}

Reinstallation is another vital part of relocation as a conservation practice. It is the stage where the final structure takes place and will be utilised for final usage.

The reinstallation method began with the fixing up the concrete base, either the platform base or the normal pad footings for elevated timber structures. The process then commenced with the reinstallation of the tiang seri or soko guru columns, followed by other supporting columns and crossbeams to fully erect the structural frames. After this temporary structure has been erected, it is critical to support this structure temporarily by using wooden bracing supports attached to the columns and crossbeams. 


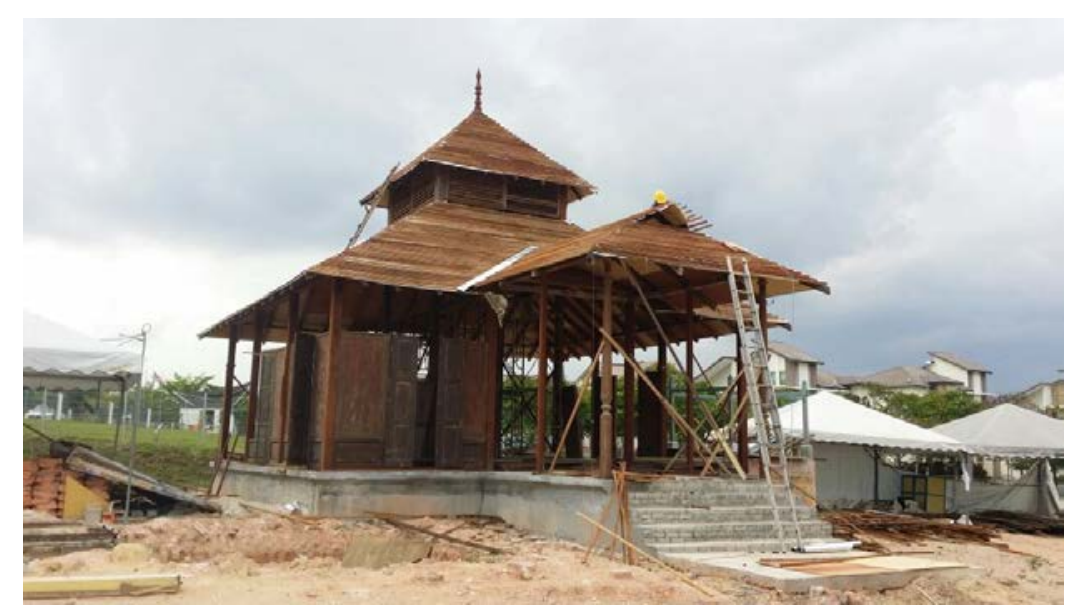

Figure 8: Wall panels are being reinstalled. (Source: ATSA Architects, 2016.)

For the roof structures, the reinstallation method begins with the rafters, tie beams, king posts, ridge end beam, pinnacle (if any), insulation ceiling (optional), purlins, upper fascia boards, roofing tile finishes, gable end walls and later the lower fascia boards. If the building may have a loft area, the loft floor joists and floorboards can be reinstalled subsequently. It was vital to complete the roof and its first structure to give shade to the internal spacing for further finishing work, such as the internal timber ceiling strips. This is comparable to the use of canopy with the other conservation works, such as repairing or adaptive reuse that deploy a large tent over the preserved building. Nevertheless, the steps can be mismatched depending on the carpenters' skills and its suitability in response to the site.

The further step involved wall panels that dominate most of the building form and façade. The wall panels can be constructed as soon as the tie beams have been put in place, as it acted as the pegging frame for the wall panels, other than the wall skirting. (Fig. 8). After the wall panels, including decorative such as latticework or any supplementary wall panels, the window and door panels can be fixed to their respective frames on the wall panels and later the balustrade of each window segment. Though, this was in the case of the Kampung Teluk Memali Mosque where some wood components had been reinstalled oddly due to the delayed in the treatment process, and also because of missing parts, which had resulted in the carpenter to remake the missing parts to allow for the rebuilding of the mosque.

The final finishing works were done partially as a when the whole structure has been completed. Many types of wood finishing can be used, either the Gori wood preservative, varnish or wood stain. If desired, the building can be painted using layers of wood coating from various brands in the market. Other civil works, such as the apron, drainage, electrical and wiring, landscaping and other finishing works were done simultaneously.

\subsection{Modern design and users' expectations}

As a 108-year old building, the Kampung Teluk Memali Mosque had to be modified and adapted to meet the current building design requirements, as well as the end users' expectations. In terms of building services, the mosque building was previously lit up with kerosene lightings, without any electrical fittings. Similarly, with the piping and sanitary installations, no water sources and sanitary available, other than a traditional well and 


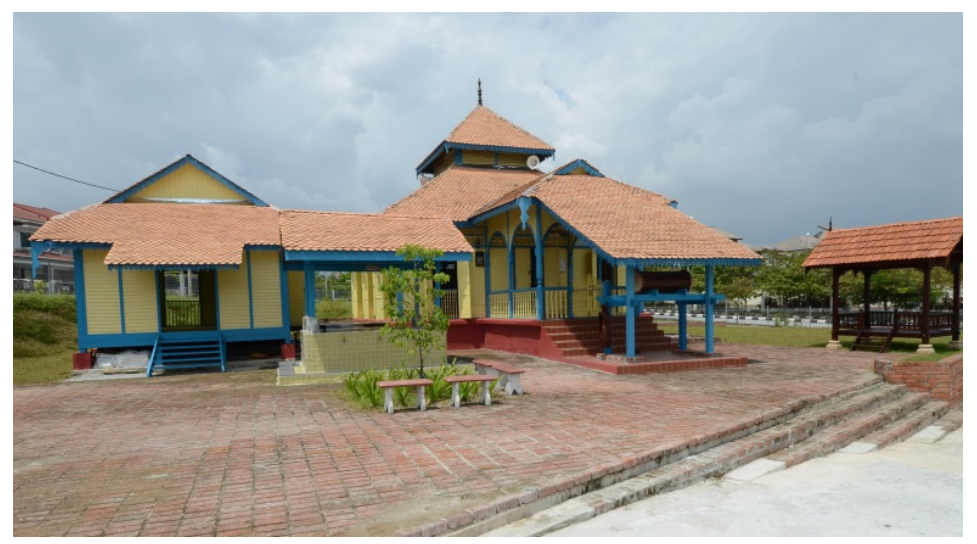

Figure 9: The completed mosque on the new site. (Source: ATSA Architects, 2017.)

ablution pond (kolah) sourced from rainwater. Most of the time, the residents had to take ablution from the nearby Perak River.

Therefore, as part of the current local authority requirements, toilet and ablution facilities with modern piping and sanitary services were provided on the new site. The electrical fittings were also installed with lightings and electric fans, along with the audiovisual system. For the final building design, many new finishes have been applied, such as the timber flooring in the main prayer hall and tile flooring for veranda and porch areas, other than Singgora roof tiles, replacing the old zinc and wooden tiles. In terms of building the structure, due to the strong natural wind of the new site, the timber structure has been reinforced with steel and bolt on top of the brick platform (Fig. 9).

\subsection{Financial factor}

As the project was a private initiative, initiated by ATSA Architects, the financial cost of the relocation of the mosque was solely done through donations from the public and various organisations. ATSA Architects spearheaded the donation drive and collected approximately RM 700,000.00 or USD 177,960.00. Funding is a crucial aspect of every conservation effort as a significant sum of money needed to restore and repair the decaying and damaged components, especially the timber structure and roof tiles without such support, it would be impossible to restore this historic mosque. It is also the most difficult task as it took a tremendous effort to raise the sum.

Extending the spirit of the community involvement, some of the building materials used in the mosque restoration effort were donated by various corporate organisations, particularly the construction suppliers, such as concrete, lights, tiles, sanitary wares and wooden carved panels. Individual donations were also made, which were also crucial in the completion of the mosque. Without these donations, the mosque restoration and relocation works will not probably be completed. The architectural consultancy services provided by ATSA Architects and conservation advice by PUO were also provided on the extra-gratis basis.

\section{CONCLUSIONS}

Often regarded as the least favourable conservation approach, this research is, however, aiming to prove that relocation is indeed a feasible conservation practice that should be 
considered whenever possible. This study has also offered insights on the idea of relocation of valuable historical buildings located in rural areas as a tool in safeguarding many timber heritage buildings in Malaysia which were often on the verge of being demolished.

Hence, the study has been examining the specific relocation methods based on the case study of this research, a relocation project by ATSA Architects, which is the relocation and restoration of Kampung Teluk Memali Mosque from Kampung Gajah, Perak to Ipoh, Perak. The exercise demonstrated many challenges that one might have encountered during the process of restoration without the full financial support from the authorities.

Therefore, the methods of relocations have been reviewed with around 48 to 57 detailed steps ranging from the earlier stages of preliminary works, dismantling process, loading and transportation, cleaning, repair and treatment and reinstallation. Based on the identified relocation methods step-by-step, the relocation methods were influenced by the carpenters' mastery and skills. The carpenters' mastery and skills are largely passed down as to carry out the traditions of their ancestors or by learning from the elderly, without any formal education and through their innate passion.

Other than the carpenters' mastery and skills, the building typologies and sizes would also influence the various relocation steps, but still retain the key elements of the traditional Malay architecture that deploy timber materials. On the transportation and storage of the dismantled components, the wood components must always be protected against the elements before proceeding with the repair and treatment works. The different repair and treatment preference also prevalent in the case study, depending on the conservators or consultant involved, but with the same goal of prolonging the durability and usage of every single timber component that was used in the building of the mosque.

\section{ACKNOWLEDGEMENTS}

In obtaining the relevant data and information for this research, the authors would like to extend the heartiest gratefulness to the project team members of relocation and restoration of Kampung Teluk Memali Mosque from ATSA Architects, other consultants including Dr. Jaki Mamat, a conservator from Ungku Omar Polytechnic (PUO), Khairudin Muhammad from the Malaysian Timber Industry Board (MTIB) and civil engineers from MNH Consultant, other than the project contractor and related construction materials suppliers.

Additionally, the authors would also like to thank officials from the Land and District Office of Central Perak, Islamic Religious and Malay Customs Council of Perak State (MAIPk), the Mufti Department of Perak State and Ipoh City Council (MBI), as well as residents of Kampung Tersusun Teluk Memali in Kampung Gajah, Perak and committee of Seri Bougainvillea Musolla, Taman Seri Bougainvillea, Bandar Seri Botani in Ipoh, Perak.

\section{REFERENCES}

[1] Killman, W., Restoring \& Reconstructing the Malay Timber House. Kepong: Forest Research Institute Malaysia, 1994.

[2] Yuan, L.J., The Malay House: Rediscovering Malaysia's Indigenous Shelter System. Penang: Institut Masyarakat, 1987.

[3] Sahabuddin, M.F., Traditional values and their adaptation in social housing design: towards a new typology and establishment of 'air house' standard in Malaysia. Edinburgh: The University of Edinburgh, 2012.

[4] Rahman, A.A., Principles of building conservation. Shah Alam: Universiti Teknologi MARA, 2015. 
[5] Wang, C.-Y., After the Removal of the Lin An-Tai Old Homestead, case study of historic buildings belong to relocation preservation in Taiwan. Taoyuan City: Chung Yuan Christian University, 2005.

[6] Feilden, B.M., Conservation of Historic Buildings. Oxford: Architectural Press, 2003.

[7] Rashid, S.D., (19 Oct. 2016). Relocation Practice in Malaysia. (M. H. Zulkifli, Interviewer), 2003.

[8] Yunos, M.Y., Masjid Lama Kampung Tersusun Teluk Memali. Ipoh: Ungku Omar Polytechnic, 2012.

[9] Arif, H.A., Perbandingan Antara Ragam Hias Gunungan Pada Mihrab dan Mimbar di Acheh dan di Tanah Melayu. Tanjung Malim: Universiti Pendidikan Sultan Idris, 2014. 